\title{
Flexural Deformation of Expanded Polystyrene Concrete Sandwich Beam: An Experimental Study
}

\author{
Rr. M. I. Retno Susilorini ${ }^{1 *}$, David Widianto ${ }^{2}$, Fransiskus Indrakusumo Ogur $^{2}$, Sigma Prabandaru ${ }^{2}$ \\ ${ }^{I}$ Department of Infrastructure and Environmental Engineering, Faculty of Environmental Science and Technology, \\ Soegijapranata Catholic University, Jl. Pawiyatan Luhur IV/1, Bendan Dhuwur, Semarang 50234, Indonesia \\ ${ }^{2}$ Department of Civil Engineering, Faculty of Engineering, Soegijapranata Catholic University, Jl. Pawiyatan Luhur IV/1, \\ Bendan Dhuwur, Semarang 50234, Indonesia
}

*Corresponding author: ORCID 0000-0001-8531-7485

\begin{abstract}
Expanded Polystyrene (EPS) concrete sandwich structure has been developed and investigated since few years ago. It has advantage of high heat resistance, impact, acoustic and vibration absorption, and easy to built. However, it is important to make benchmarking of the local product of (EPS) concrete sandwich structure and the global product. Therefore, this research aims to investigate the flexural deformation of local product of EPS concrete sandwich beams such as its deflection, peak load, and flexural strength. There are 9 EPS concrete sandwich beams were tested for flexural strength with dimension of $\mathrm{L} \times 200 \times 7.5 \mathrm{~mm}$, where $\mathrm{L}$ were three specific lengths of 50,100, and $100 \mathrm{~mm}$. The flexural test carried out by Universal Testing Machine, LVDT, and data logger. The experiment has shown that Optimum values of maximum deflection, peak load, and flexural strength, achieved by series II of the specimens. There was a "jigsaw phenomenon" during the loading of series II and III. Optimum values of EPS concrete sandwich beam achieved by series II with length of $100 \mathrm{~mm}$. It has peak load of $4.39 \mathrm{kN}$, flexural strength of $3.42 \mathrm{MPa}$ and maximum deflection of $2.47 \mathrm{~mm}$. The research found that the local product of EPS concrete sandwich beam used as specimens in this research complies with the previous investigation and application.
\end{abstract}

Keywords: flexural, deformation, expanded polystyrene, concrete, sandwich beam.

\section{INTRODUCTION}

Concrete sandwich structure has been developed since many decades ago due to its high heat resistance, impact, acoustic and vibration absorption, and easy to built [1]. This type of concrete fulfilled the need of lightweight materials for high rise building and still developed until nowadays. First studies by [2] and [3] delivered theories of sandwich structures which previously were implemented by application of Expanded Polystyrene (EPS) in 1957[4]. It was EPS concrete sandwich panel that used because of its advantage of low density and best insulation ability. Instead of the EPS concrete sandwich can transfer load and insulate structure perfectly, it has low compressive strength as about less than $10 \mathrm{MPa}$. Several researches have been carried out to develop EPS and other materials for concrete sandwich structures such as [5-13].

Previous investigations have been developed and studied the performance of EPS concrete sandwich structure, but little information available about the study of local manufactures EPS concrete sandwich structure. It is important to make benchmarking of the quality of the EPS concrete sandwich structure to the global product, hence this research conducted especially in investigating the flexural deformation of local product of EPS concrete sandwich beams. This research aims to study deflection, peak load, and flexural strength of EPS concrete sandwich beams that expected meets the quality of the global product.

\section{MATERIALS AND METHODS}

\section{II.I. Materials}

EPS concrete sandwich used in this research was a panel of $240 \times 61 \times 7.5 \mathrm{~m} 3$ which was cut and used as beam. The appearance of a EPS concrete sandwich block shown by Fig that consist of facings (skins) and core as described by Fig 2 [14]. The height of EPS concrete sandwich beam was $7.5 \mathrm{~m}$ with facing width of $6 \mathrm{~mm}$.

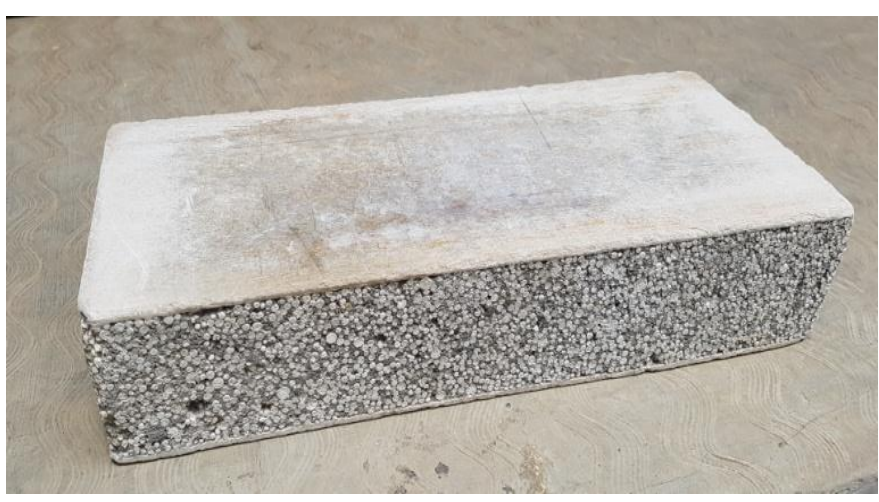

Fig 1. EPS concrete sandwich block 


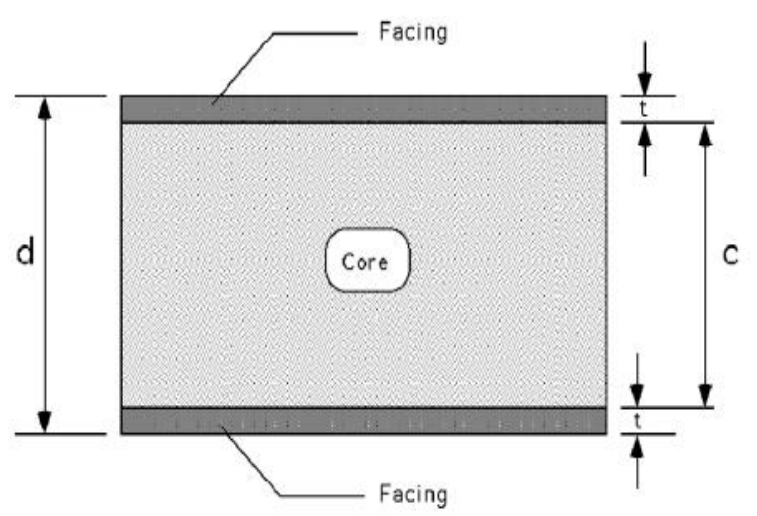

Fig 2. EPS concrete sandwich block cross-section

There were 9 beam specimens prepared for flexural test of third point loading that referred to ASTM C393/C393M Standard Test Method for Core Shear Properties of Sandwich Constructions by Beam Flexure. Dimension for beam specimens described by Table 1 .

Table 1. EPS concrete sandwich beam dimension

\begin{tabular}{|c|c|c|c|c|}
\hline \multirow{2}{*}{$\begin{array}{c}\text { specimen } \\
\text { series }\end{array}$} & $\begin{array}{c}\text { length } \\
(\mathrm{L})\end{array}$ & $\begin{array}{c}\text { width } \\
(\mathrm{b})\end{array}$ & $\begin{array}{c}\text { height } \\
(\mathrm{h})\end{array}$ & $\begin{array}{c}\text { total } \\
\text { specimen }\end{array}$ \\
\cline { 2 - 5 }$(\mathrm{mm})$ & $(\mathrm{mm})$ & $(\mathrm{mm})$ & $(\mathrm{pcs})$ \\
\hline I & 500 & 200 & 75 & 3 \\
\hline II & 1,000 & 200 & 75 & 3 \\
\hline III & 1,500 & 200 & 75 & 3 \\
\hline
\end{tabular}

\section{II.II. Experimental Program}

Flexural Test for beam specimens was carried out by loading frame and also Universal Testing Machine (UTM) of Hung Ta HT-EH 21016 with application of Linear Variable Displacement Transducer (LVDT) and Data Logger of Schumy Data Logger TML, Type S-2251 (Fig 3). UTM was recording displacement, load, and time during the test.

Flexural strength of beams was calculated by Equation (1) that referred to Indonesia National Standard of SNI-03-4431-1997 Methods of Normal Flexural Test of Two Points Loading as follow.

$$
\sigma=\frac{\mathrm{P} \cdot \mathrm{L}}{\mathrm{b} \cdot \mathrm{h}^{2}}
$$

Where:

$$
\begin{aligned}
\sigma & =\text { flexural strength of beam }(\mathrm{MPa}) \\
\mathrm{P} & =\text { load }(\mathrm{kN}) \\
\mathrm{L} & =\text { beam span }(\mathrm{mm}) \\
\mathrm{b} & =\text { width of horizontal cross-section }(\mathrm{mm}) \\
\mathrm{h} & =\text { heigth of vertical cross-section }(\mathrm{mm}) \\
\mathrm{a} & =\text { average value of space between cracked } \\
& \text { cross-section and nearest outer support } \\
& (\mathrm{mm})
\end{aligned}
$$

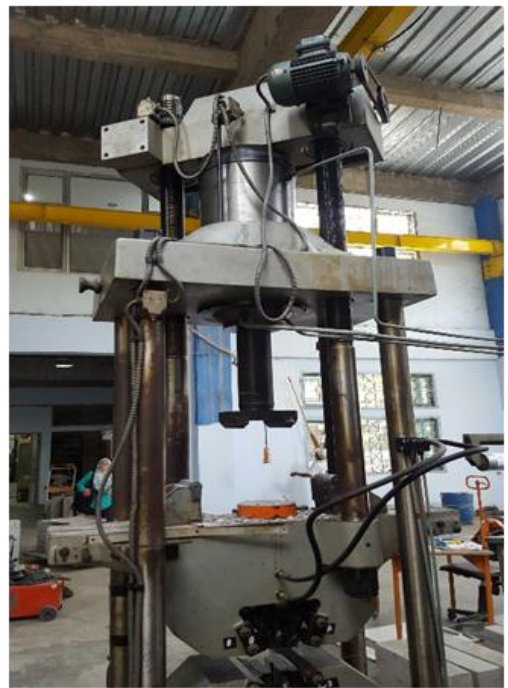

Fig 3. Universal Testing Machine with LVDT and Data Logger

\section{RESULT}

All specimens were successfully tested for flexure strength as shown by Fig 4. Flexural test was carried out until beam specimens were getting collapse (Fig 5) and broken into pieces (Fig 6). Load-time, load-deflection, and deflection-time relations of the beam specimens will be explained as follow.

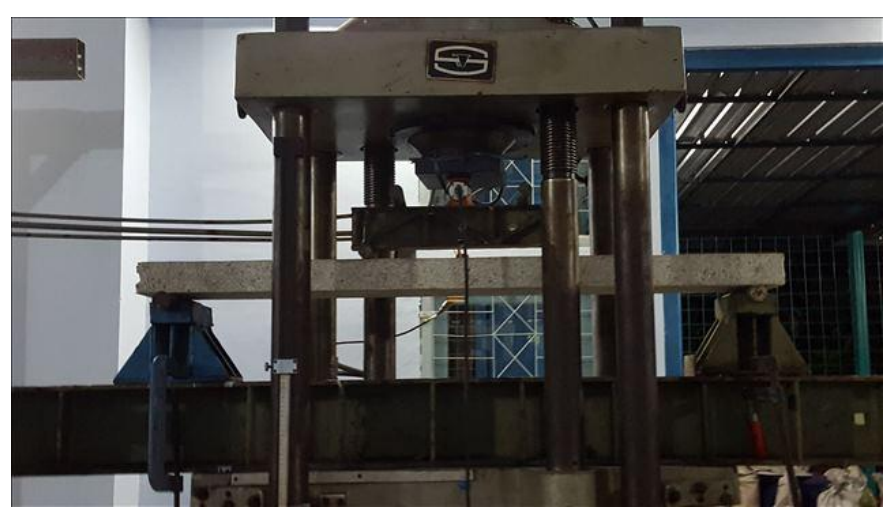

Fig 4. Flexural Test of Specimens IIIA

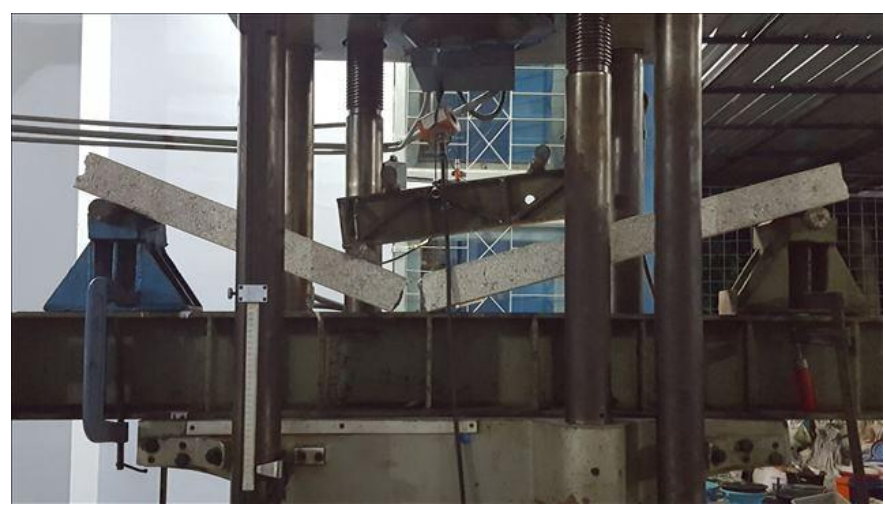

Fig 5. Beam specimen was getting collapse after reach maximum deflection 
International Journal of Engineering Research and Technology. ISSN 0974-3154 Vol.13, No.3 (2020), pp. $540-547$

(C) International Research Publication House. https://dx.doi.org/10.37624/IJERT/13.3.2020.540-547

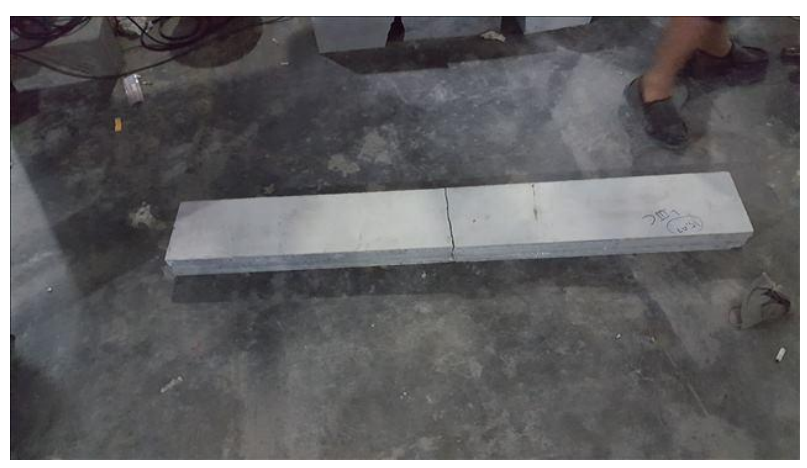

Fig 6. Crack pattern of collapsed beam specimen

\section{III.I. Specimen IA}

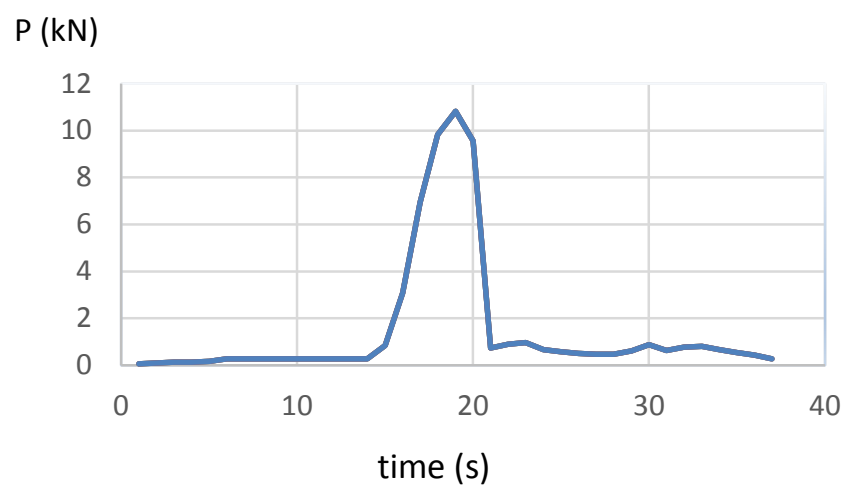

Fig 7. Load-time relation of specimen IA

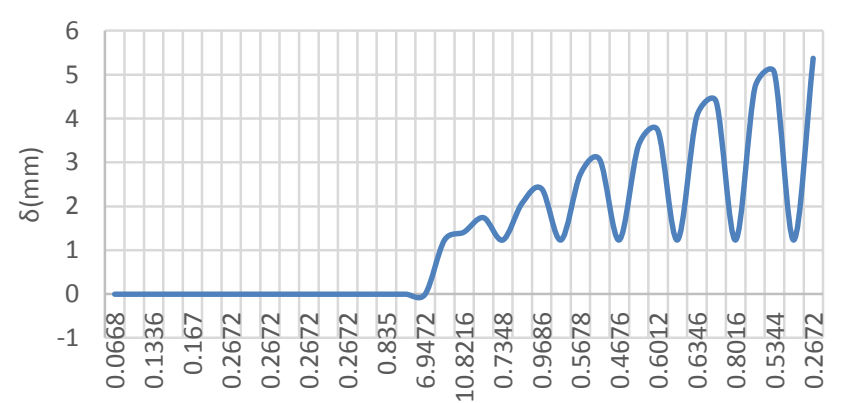

$$
\mathrm{P}(\mathrm{kN})
$$

Fig 8. Deflection-stress relation of specimen IA

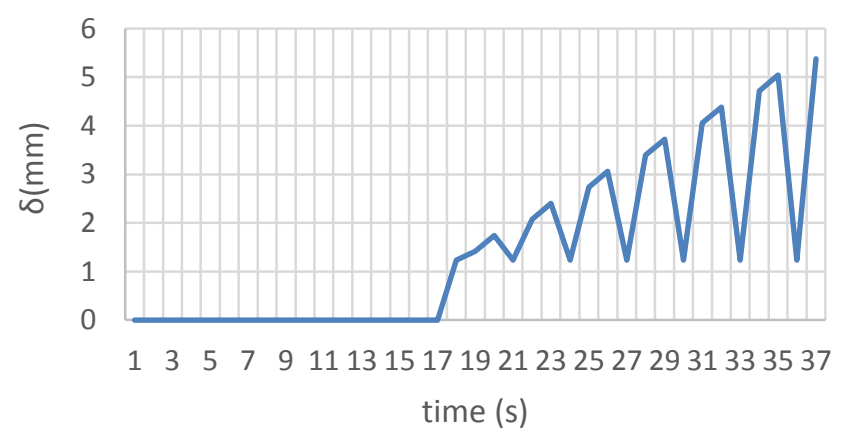

Fig 9. Deflection-time relation of specimen IA
Specimen IA achieved peak load of $0.262 \mathrm{kN}$ at 18 seconds and had deflection of $6.658 \mathrm{~mm}$ at 37 seconds as decribed by Fig 7., Fig 8., and Fig 9. First crack appeared at 17 seconds that shown by Fig 9 . There was about 20 seconds prior to the time of maximum deflection (Fig 7) achieved after the peak load (Fig 8).

\section{III.II. Specimen IB}

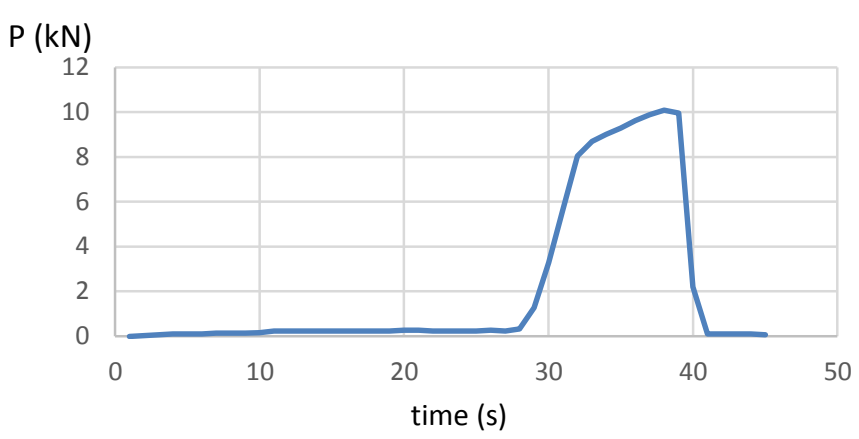

Fig 10. Load-deflection relation of specimen IB

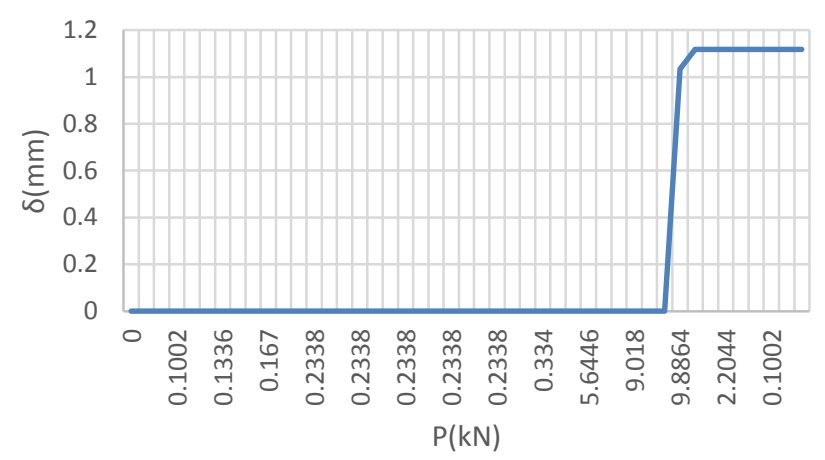

Fig 11. Load-time relation of specimen IB

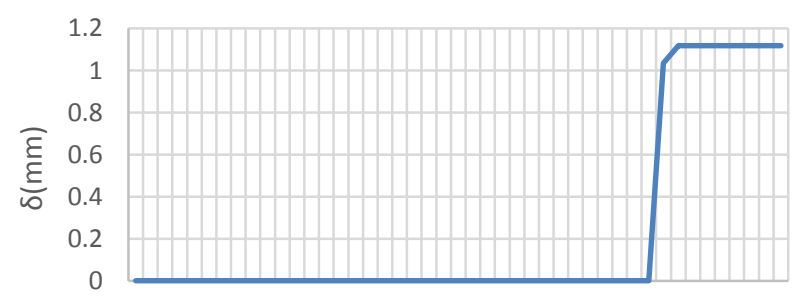

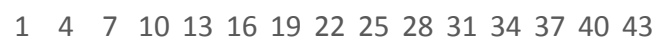

time (s)

Fig 12. Deflection-time relation of specimen IB

Specimen IB performed a little bit different behaviour compared to specimen IA. Peak load of $10.0868 \mathrm{kN}$ was achieved at 38 seconds while maximum deflection of 3.26 $\mathrm{mm}$ existed at 37 seconds as described by Fig 10., Fig 11., and Fig 12. First crack appeared at 27 seconds (Fig 10) and it was just jumped up to peak load at 37 seconds that shown by Fig 11 and Fig 12. There was only about 7 seconds before specimen was getting collapsed. 


\section{III.III. Specimen IC}

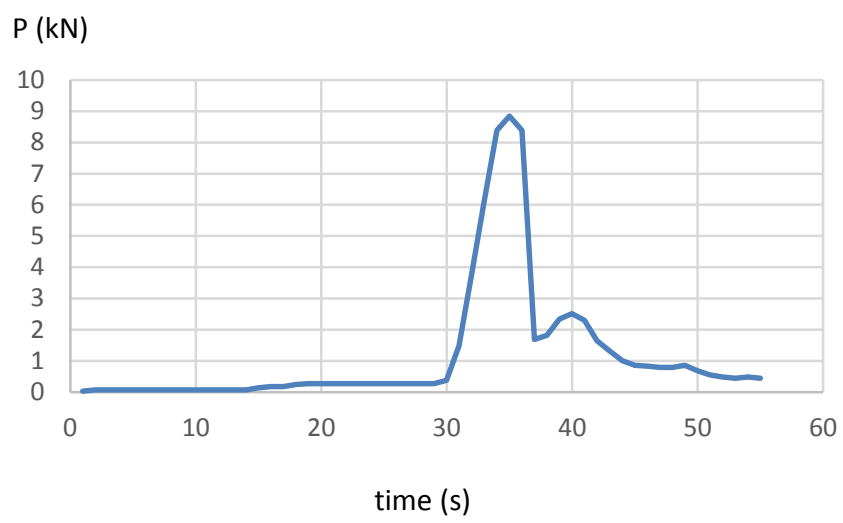

Fig 13. Load-deflection relation of specimen IC

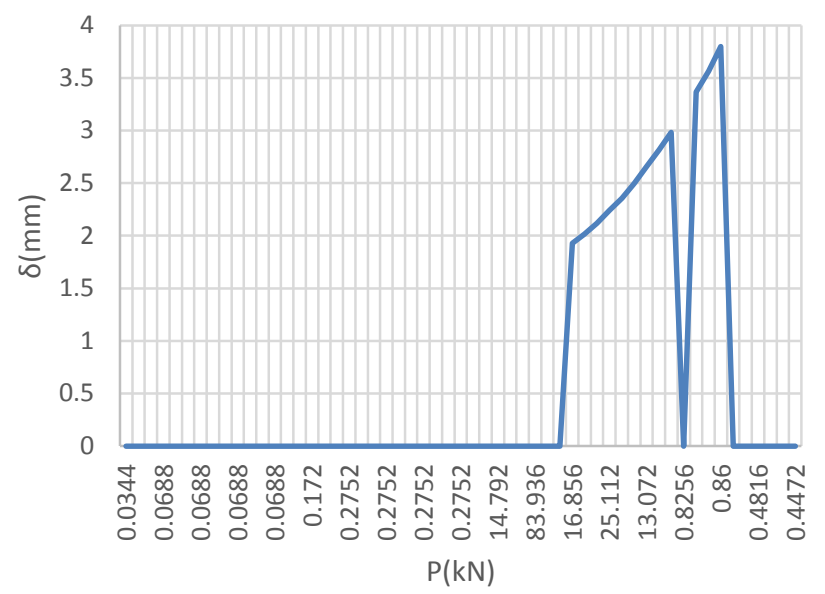

Fig 14. Load-time relation of specimen IC

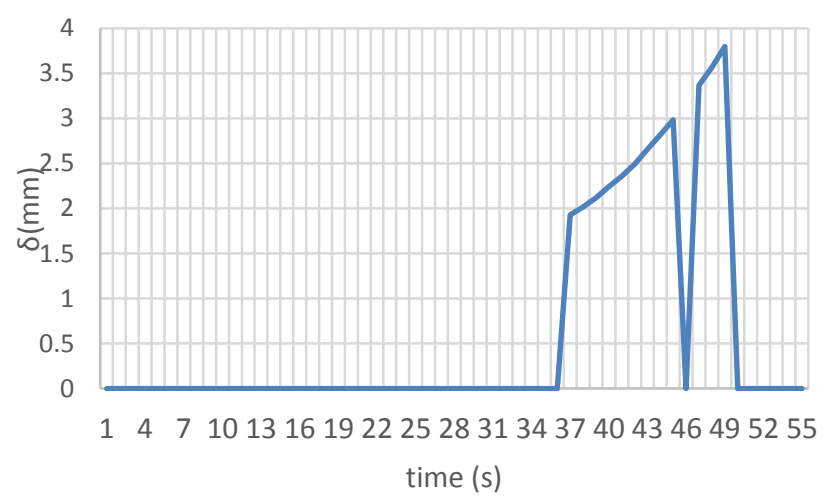

Fig 15. Deflection-time relation of specimen IC

The case of specimen IC was similar to specimen IB unless there was longer time before specimen collapsed. Specimen IC achieved peak load of $8.8404 \mathrm{kN}$ at 35 seconds while maximum deflection of $4.03 \mathrm{~mm}$ existed at 55 seconds as described by Fig 13., Fig 14., and Fig 15. However, Fig 15 has shown that there was a lag in the end of loading that the load jumped nearly to zero but increased again to achieve peak load before collapsed.

\section{III.IV. Specimen IIA}

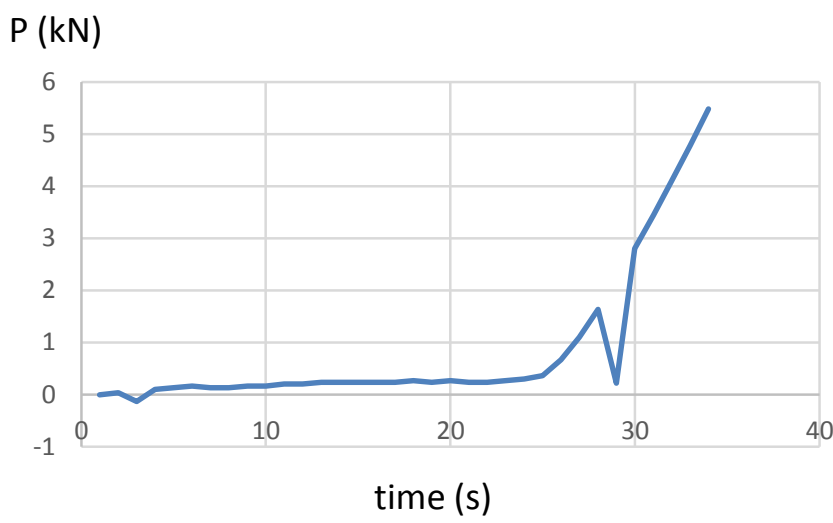

Fig 16. Load-deflection relation of specimen IIA

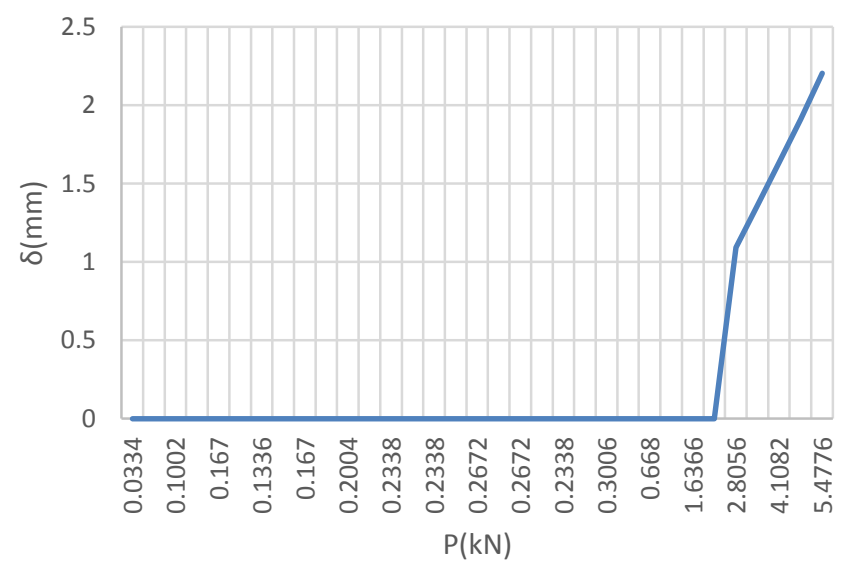

Fig 17. Load-time relation of specimen IIA

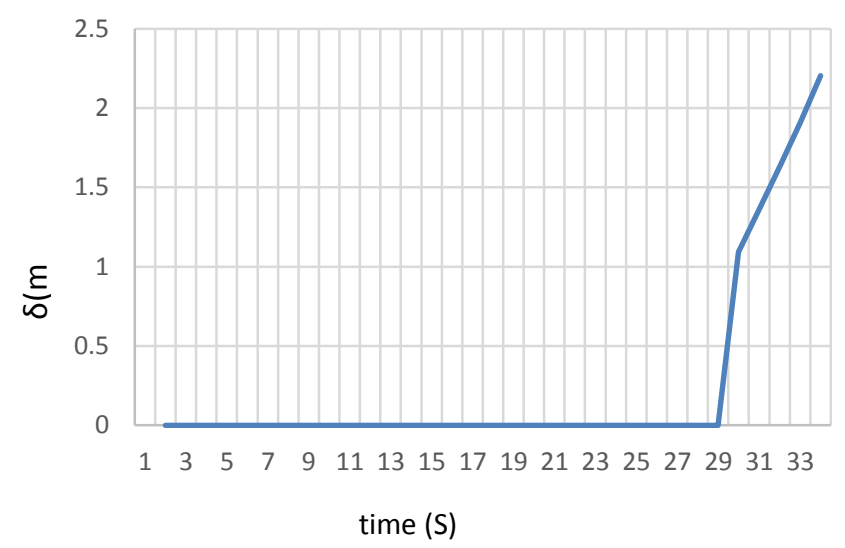

Fig 18. Deflection-time relation of specimen IIA

The series of II specimens were twice longer than the series of I specimens. Hence, different performance has been established. Specimen IIA achieved peak load of $5.4776 \mathrm{kN}$ at 34 seconds while maximum deflection of $2.204 \mathrm{~mm}$ existed as described by Fig 16., Fig 17., and Fig 18. It was shown by Fig 16 that cracks existed at 4 seconds and right after the peak load achieved and the specimen collapsed. 
International Journal of Engineering Research and Technology. ISSN 0974-3154 Vol.13, No.3 (2020), pp. $540-547$

(C) International Research Publication House. https://dx.doi.org/10.37624/IJERT/13.3.2020.540-547

\section{III.V. Specimen IIB}

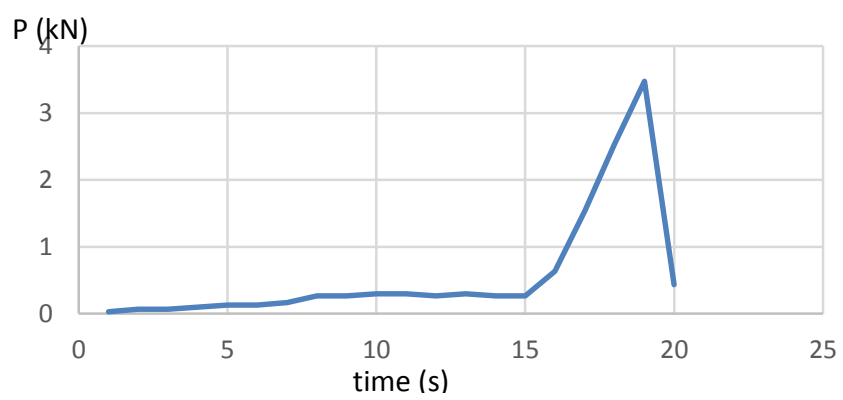

Fig 19. Load-deflection relation of specimen IIB

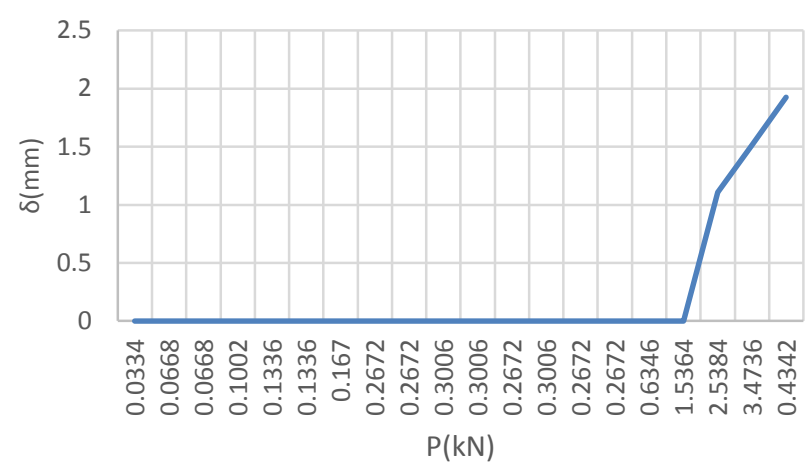

Fig 20. Load-time relation of specimen IIB

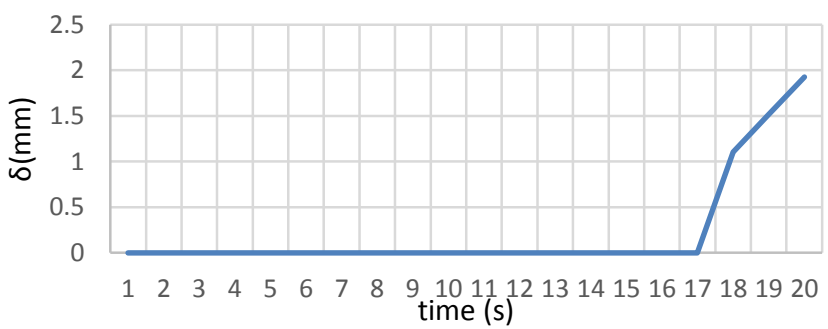

Fig 21. Deflection-time relation of specimen IIB

Specimen IIB had shorter time (19 seconds) to collapse compared to specimen IIA. It achieved peak load of 3.4736 $\mathrm{kN}$ at 19 seconds while maximum deflection of $1.926 \mathrm{~mm}$ happened at load of $0.4342 \mathrm{kN}$ as described by Fig 19., Fig 20., and Fig 21. It was shown by Fig 16 that right after the peak load achieved the specimen collapsed.

\section{III.VI. Specimen IIC}

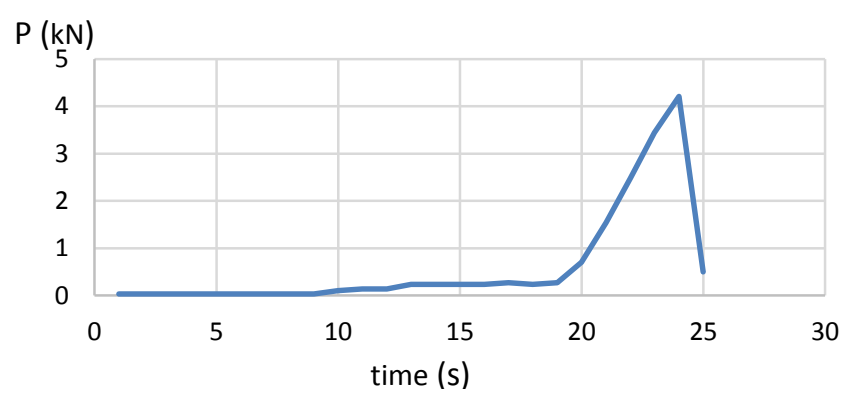

Fig 22. Load-deflection relation of specimen IIC

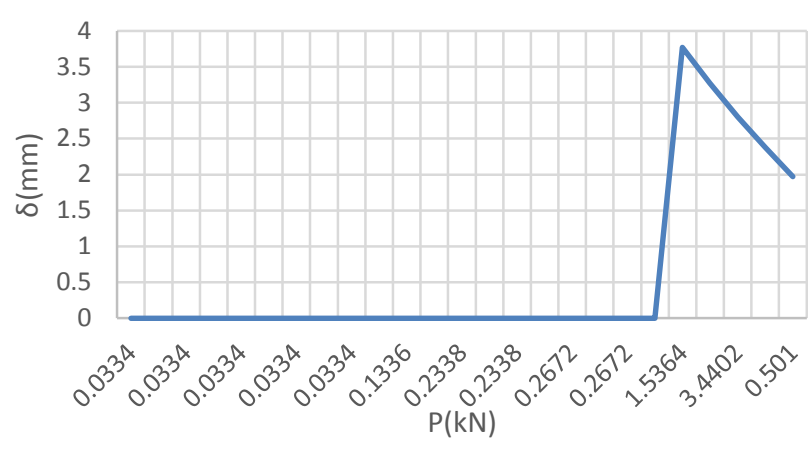

Fig 23. Load-time relation of specimen IIC

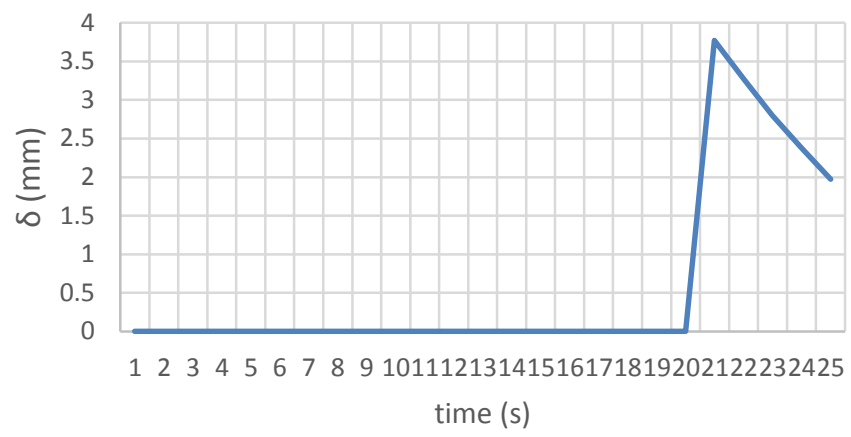

Fig 24. Deflection-time relation of specimen IIC

Even though specimen IIB has short period of collapse, specimen IIC performed better. The peak load of $4.2 \mathrm{kN}$ achieved by specimen IIC at 24 seconds while maximum deflection of $4.236 \mathrm{~mm}$ existed at load of $1.5 \mathrm{kN}$ (Fig 22., Fig 23., and Fig 24.). Time to specimen collapsed was 35 seconds.

\section{III.VII. Specimen IIIA}

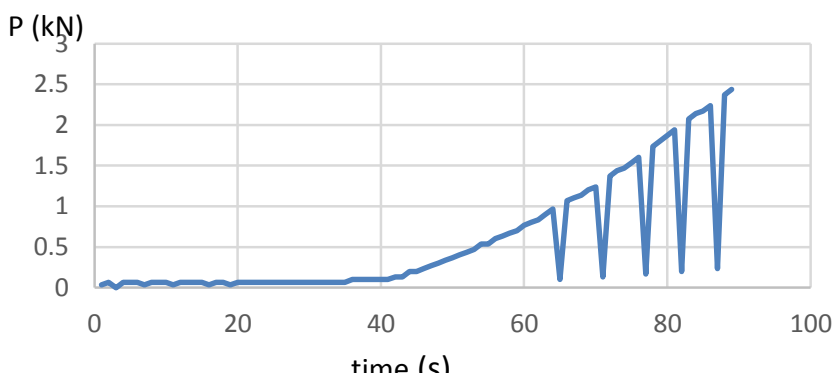

Fig 25. Load-time relation of specimen IIIA

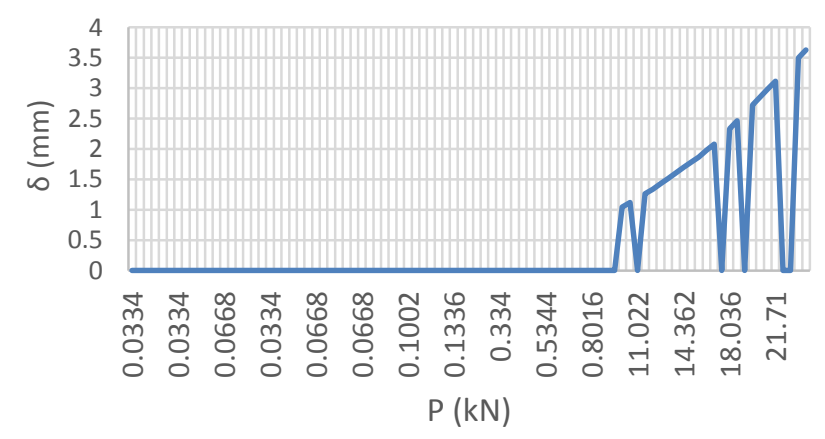

Fig 26. Load-deflection relation of specimen IIIA 


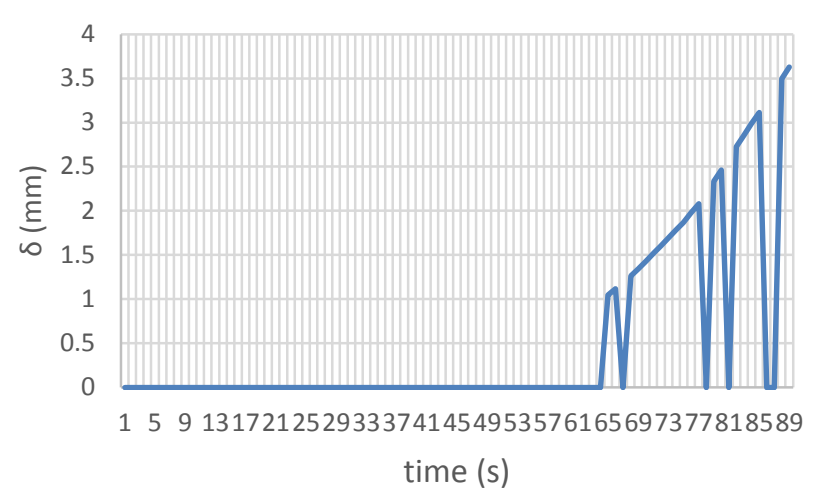

Fig 27. Deflection-time relation of specimen IIIA

The series of III of specimens were three times longer than the series of I specimens to get collapesed. Therefore, there was significant behaviour existed during the loading. Specimen IIIA performed gradual increase of load at 40 seconds to 88 seconds (Fig 25) with "jigsaw phenomenon" (Fig 26 and Fig 27). Specimen IIIA achieved peak load of $2.3724 \mathrm{kN}$ at 88 seconds while maximum deflection of $3.638 \mathrm{~mm}$.

\section{III.VIII. Specimen IIIB}

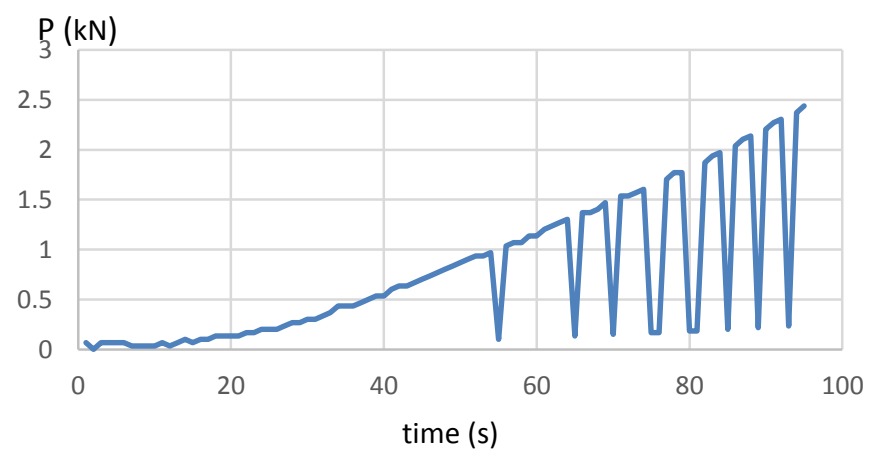

Fig 28. Load-deflection relation of specimen IIIB

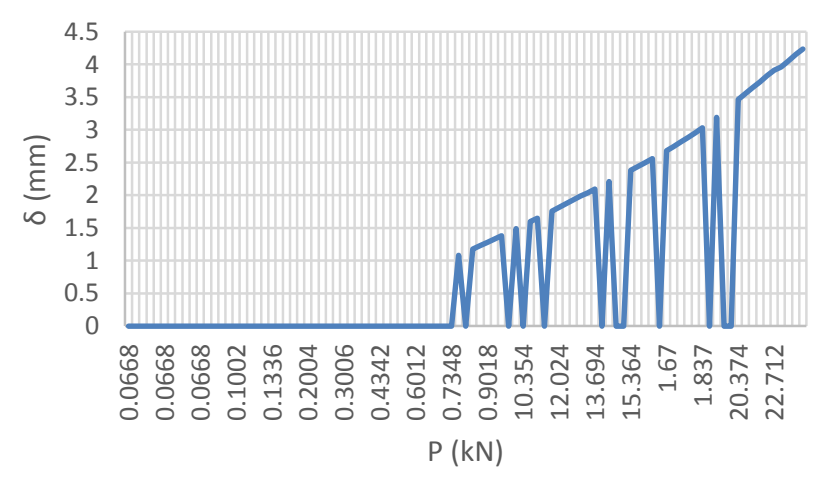

Fig 29. Load-deflection relation of specimen IIIB

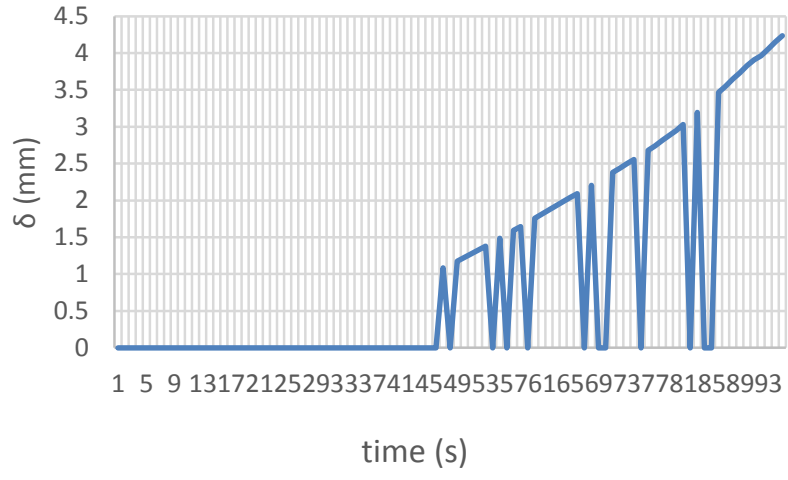

Fig 30. Deflection-time relation of specimen IIIB

It was found that specimen IIIB had longer time (95 seconds) to collapse compared to specimen IIIA. It achieved peak load of $2.382 \mathrm{kN}$ at 95 seconds while maximum deflection of $4.0512 \mathrm{~mm}$ as described by Fig 28., Fig 29., and Fig 30. Gradual load increase was established from the initial of loading (Fig 28.).

\section{III.IX. Specimen IIIC}

$P(k N)$

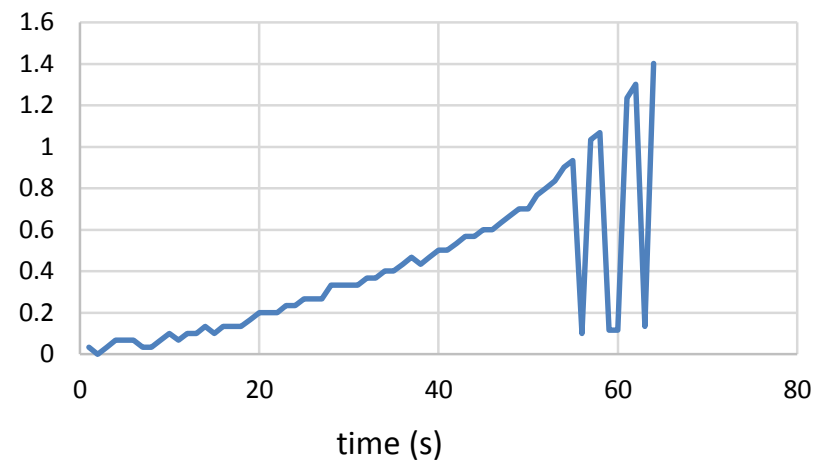

Fig 31. Load-deflection relation of specimen IIIC

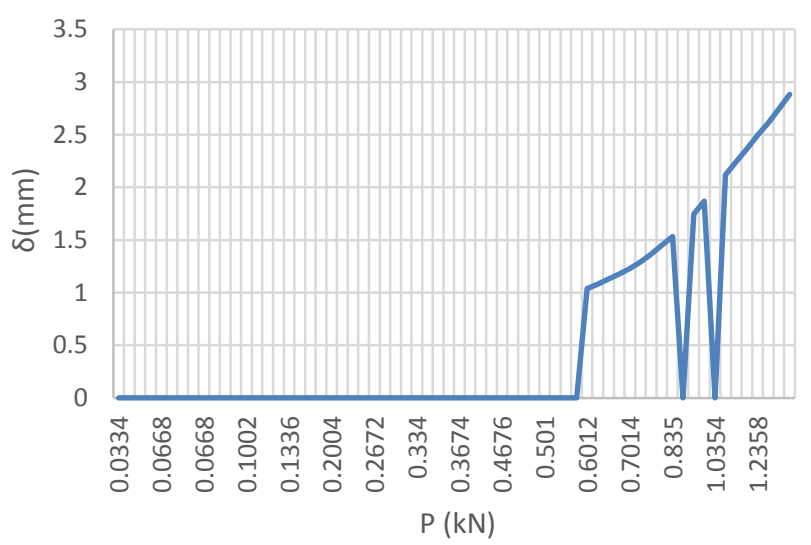

Fig 32. Load-deflection relation of specimen IIIC 


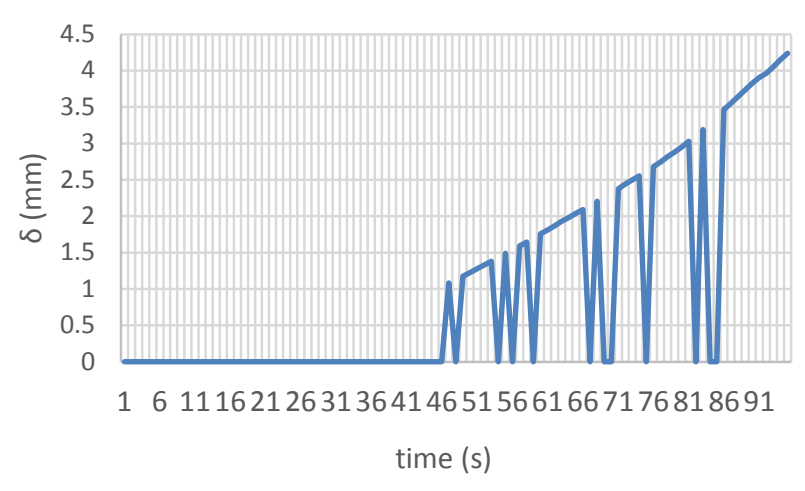

Fig 33. Deflection-time relation of specimen IIIC

Specimen IIIC performed shorter time to collapse (64 seconds) as shown by Fig 31. Similar to specimen IIA, right after achieving peak load $1.4028 \mathrm{kN}$, specimen IIIC was collapsed (Fig 31.) Maximum deflection of $4.056 \mathrm{~mm}$ existed at 95 seconds. Phenomenon of "jigsaw" also existed during the loading (Fig 32 and Fig 33).

\section{DISCUSSION}

Flexural test has been carried out for all specimens and the flexural strength were calculated based on the experimental result as detailed by Table 2 . Highest flexural strength was achieved by series II (3.42), follow by series I (3.06), and series III (2.67). Results of Fig 7 to Fig 33 have shown that the longer specimens the lower peak load can be achieved. However, deflection of the specimen series performed nonlinear behaviour since the lowest deflection achieved by series II, followed by series III and series I as described by Fig 34. It is also found that deflection-time relation specimen series was not linear relation. Series II has shorter time of maximum deflection, followed by series I and series III.
Optimum values of maximum deflection, peak load, and flexural strength, achieved by series II of the specimens. This finding confirms the study [15] of that concrete sandwich beam $(2.5 \mathrm{~m} \times 20 \mathrm{~cm} \times 20 \mathrm{~mm})$ containing EPS (and also Textile Reinforced Cementitious Composites, TRCs) can have maximum deflection about $45 \mathrm{~mm}$ and peak load about 5 $\mathrm{kN}$.Hence, the optimum length of EPS concrete sandwich beam is $100 \mathrm{~mm}$, which can be implemented to field application.

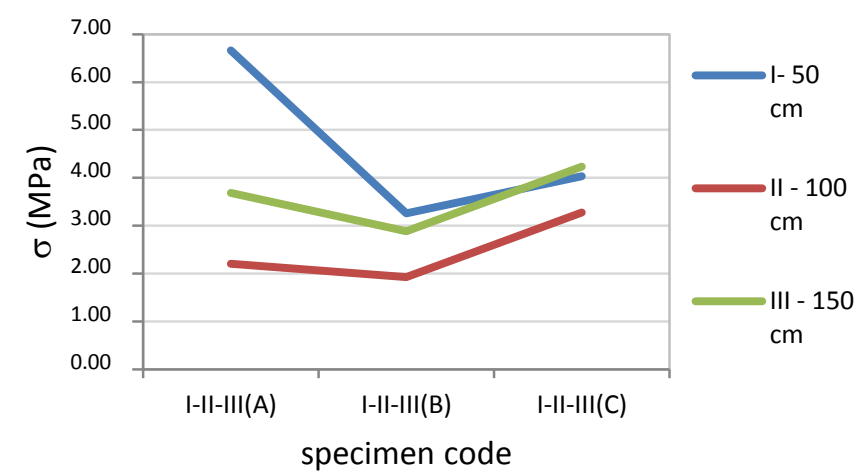

Fig 34. Deflection of the specimen series

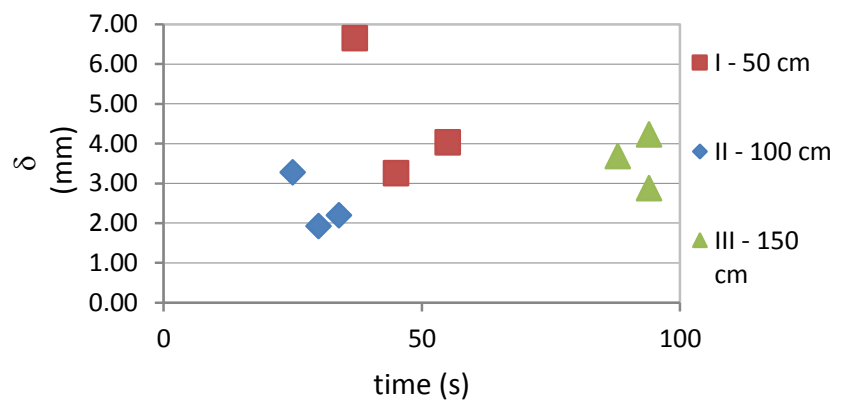

Fig 35. Deflection-time relation of the specimen series

Table 2. Flexural strength of EPS sandwich beam specimens*

\begin{tabular}{|c|c|c|c|c|c|c|c|c|c|}
\hline \multirow[t]{2}{*}{$\begin{array}{l}\text { specimen } \\
\text { code }\end{array}$} & $\begin{array}{c}\text { load } \\
(\mathrm{P})\end{array}$ & $\begin{array}{l}\text { length } \\
\text { (L) }\end{array}$ & $\begin{array}{l}\text { width } \\
\text { (b) }\end{array}$ & $\begin{array}{l}\text { height } \\
\text { (h) }\end{array}$ & weight & $\begin{array}{c}\text { span } \\
\text { between } \\
\text { two } \\
\text { supports }\end{array}$ & $\begin{array}{l}\text { deflection } \\
(\delta)\end{array}$ & $\begin{array}{l}\text { flexural } \\
\text { strength } \\
(\sigma)\end{array}$ & $\begin{array}{l}\text { flexural } \\
\text { strength } \\
\qquad(\sigma) \\
\text { average }\end{array}$ \\
\hline & $(\mathrm{N})$ & $(\mathrm{mm})$ & $(\mathrm{mm})$ & $(\mathrm{mm})$ & $(\mathrm{kg})$ & $(\mathrm{mm})$ & $(\mathrm{mm})$ & $(\mathrm{MPa})$ & (MPa) \\
\hline IA & 10.82 & 500 & 200 & 75 & 5.40 & 350 & 6.66 & 3.38 & \multirow[b]{3}{*}{3.06} \\
\hline IB & 10.09 & 500 & 200 & 75 & 5.51 & 350 & 3.26 & 3.15 & \\
\hline IC & 8.84 & 500 & 200 & 75 & 4.89 & 350 & 4.03 & 2.63 & \\
\hline IIA & 5.48 & 1,000 & 200 & 75 & 9.62 & 850 & 2.20 & 4.24 & \multirow[b]{3}{*}{3.42} \\
\hline IIB & 3.47 & 1,000 & 200 & 75 & 10.64 & 850 & 1.93 & 2.73 & \\
\hline IIC & 4.21 & 1,000 & 200 & 75 & 10.26 & 850 & 3.27 & 3.28 & \\
\hline IIIA & 2.44 & 1,500 & 200 & 75 & 15.85 & 1350 & 3.68 & 3.09 & \multirow[b]{3}{*}{2.67} \\
\hline IIIB & 2.44 & 1,500 & 200 & 75 & 15.68 & 1350 & 2.88 & 3.09 & \\
\hline IIIC & 1.03 & 1,500 & 200 & 75 & 15.47 & 1350 & 4.24 & 1.85 & \\
\hline
\end{tabular}

*Reported by authors in [5] 


\section{CONCLUSION}

This research found that flexural deformation of EPS concrete sandwich beam will perform optimum by the length of 100 $\mathrm{mm}$. It has peak load of $4.39 \mathrm{kN}$, flexural strength of 3.42 $\mathrm{MPa}$ and maximum deflection of $2.47 \mathrm{~mm}$. However, the authors suggest thicker facing of EPS concrete sandwich beam and better quality of epoxy to increase flexural strength and bonding mechanism. After all, the local product of EPS concrete sandwich beam used as specimens in this research complies with the previous investigation and application.

\section{ACKNOWLEDGMENT}

The authors gratefully acknowledge the courtesy and funding of PT Indostar Modular to the research. The funding was carried out for the research entitled "Innovation of Sandwich Concrete Styrofoam Sandwich Technology” 2017.

\section{REFERENCES}

[1] Magnucki, K., Smyczyński, M., Jasion, P. Deflection and strength of a sandwich beam with thin binding layers between faces and a core. Archives of Mechanics. 2013. 65(4). Pp. 301-311. DOI:10.24423/aom.884.

[2] Plantema, F.J. Sandwich construction. John Wiley\&Sons. New York, London, Sydney, 1966.

[3] H.G. Allen. Analysis and design of structural sandwich panels. Pergamon Press: Oxford. London, Edinburgh, New York, Toronto, Sydney, Paris, Braunschweig, 1969.

[4] Lee, J.H., Kang, S.H., Ha, Y.J., Hong, S.G. Structural Behavior of Durable Composite Sandwich Panels with High Performance Expanded Polystyrene Concrete. International Journal of Concrete Structures and Materials. 2018. 12(1). DOI:10.1186/s40069-0180255-6. URL: https://doi.org/10.1186/s40069-0180255-6.

[5] Ogur, FI., Prabandaru, S. Flexural Performance of Concrete Sandwich Beam with Styrofoam (Kinerja Lentur Pada Balok Beton Sandwich Dengan Isian Styrofoam). Undergraduate Thesis, Department of Civil Engineering, Faculty of Engineering, Soegijapranata Catholic University, Semarang, Indonesia, 2017.

[6] Fajrin, J., Zhuge, Y., Bullen, F., Wang, H. Flexural strength of sandwich panel with lignocellulosic composites intermediate layer-a statistic approach. International Journal of Protective Structures. 2011. 2(4). Pp. 453-464. DOI:10.1260/2041-4196.2.4.453.

[7] Salet, T.A.M. Structural Analysis of Sandwich Beams Composed of Reinforced Concrete Faces and a Foamed Concrete Core. (1990)1990.
[8] Liu, Q., Du, W., Uddin, N., Zhou, Z. Flexural Behaviors of Concrete/EPS-Foam/Glass-Fiber Composite Sandwich Panel. Advances in Materials Science and Engineering. 2018. 2018. DOI:10.1155/2018/5286757.

[9] Kazem, H., Bunn, W.G., Seliem, H.M., Rizkalla, S.H., Gleich, H. Durability and long term behavior of FRP/foam shear transfer mechanism for concrete sandwich panels. Construction and Building Materials. 2015. 98. Pp. 722-734. DOI:10.1016/j.conbuildmat.2015.08.105. URL: http://dx.doi.org/10.1016/j.conbuildmat.2015.08.105.

[10] Parung, H., Tjaronge, M.W., Djamaluddin, R. The Effect of Use Styrofoam for Flexural Characteristics of Reinforced Concrete Beams. 2013. (Icetd). Pp. 261272.

[11] Sadeghian, P., Hristozov, D., Wroblewski, L. Experimental and analytical behavior of sandwich composite beams: Comparison of natural and synthetic materials. 20(3)2018.

[12] Far, H., Far, C. Long-term structural behaviour of composite sandwich panels. World Congress on Civil, Structural, and Environmental Engineering. 2017. Pp. 1-8. DOI:10.11159/icsenm17.118.

[13] Yalkin, H.E., Icten, B.M., Alpyildiz, T. Tensile and compressive performances of foam core sandwich composites with various core modifications. Journal of Sandwich Structures and Materials. 2017. 19(1). Pp. 49-65. DOI:10.1177/1099636216650819.

[14] Hanif Hasbi Ardin, R., Ariesta, Y., Retno Susilorini dan David Widianto, R.M. Creep Performance of (Cement EPS Sandwich Panel) Concrete Beam (Kinerja Rangkak pada Balok Beton Sandwich dengan Isian Styrofoam/Cement EPS Sandwich Panel). Teknik Sipil Unika Soegijapranata Semarang |. 2017. 1. Pp. 2620-5297.

[15] Munck, M. De, Vervloet, J., Kadi, M. El, Verbruggen, S., Wastiels, J., Tysmans, T., Remy, O. Repeated Loading of Cement Composite Sandwich Beams. $\begin{array}{llll}\text { Proceedings. } & 2018 . & 2(8) . & \text { Pp. }\end{array}$ DOI:10.3390/icem18-05353. 